\title{
Major barriers for participating in online teaching in developing countries from Iranian faculty members' perspectives
}

\author{
Bibi Eshrat Zamani \\ Faculty of Education and Psychology, University of Isfahan, Iran
}

Azam Esfijani

Faculty of Education and Psychology, University of Isfahan, Iran

\author{
Seyed Majid Abdellahi Damaneh
}

Payame-noor University, Iran

\begin{abstract}
Although higher education systems in developing countries such as Iran have embraced the online education approach, they are confronted with significant challenges in this transition, one of which is lack of instructors' participation in online teaching. Therefore, this research is aimed at exploring barriers and influential factors for this lack of participation. The researchers developed their theoretical framework based on a thorough review of the existing body of knowledge while considering the cultural features of Iran as a developing country. A tailored questionnaire asking about the existence of three groups of barriers, namely personal, attitudinal and contextual inhibitors, was distributed among all faculty members who were candidates for delivering online courses in one of the top universities in the country. Data was analysed using the descriptive and inferential tests of Friedman, $t$ Test and ANOVA. The results were in line with research findings in other developing countries in which the contextual barriers had the most inhibition effect against faculty members' participation in online teaching. Certain cultural barriers also are highlighted by participants, pertaining to the context of Iranian online education systems.
\end{abstract}

\section{Introduction}

The call for tertiary education institutions to move to online education mode has been resonating in the higher education domain in Iran, as in to other countries around the world. Considering the significant advantages that online education can add to the process of teaching and learning, Iranian universities have embraced the new approach. As the movement to the new approach is in its early stages, it is associated with challenges and issues, one of which is the lack of faculty members' involvement in online teaching. Scholars have adopted various perspectives in attempting to research instructors as one of the major components in online education systems (Al-alak \& Alnawas, 2011; Bolliger, Inan, \& Wasilik, 2014; Islam, 2012; Reed, 2012; Richardson \& Alsup, 2015). However in Iran, as a developing country, this aspect has still not received enough research attention.

There is no doubt that for a successful transition from on campus classrooms to online ones, instructors play an important role. However, many studies noted instructors' resistance to accepting new technologies as one of the major obstacles for developing online educational programs (Benson, Anderson, \& Ooms, 2011; Blin \& Munro, 2008; Kowalczyk, 2014). In the process of implementing an online learning environment as a new educational setting, instructors usually responded with a variety of levels of engagement in leveraging new technologies (Panda \& Mishra, 2007; Seaton \& Schwier, 2014). It is also mentioned that in the adoption process of new innovations, faculty members' problems in understanding and interacting with new innovations are even more important than the problems related to infrastructure obstacles (McNeil, 1990). This means the former is a more important obstacle in acceptance and development of the new technology based approaches.

The existing literature reveals many different obstacles discouraging teachers from engaging with online teaching. For instance, additional workload, inadequate support and rewards, lack of control and authority, technical problems, time limitations, concerns about intellectual assets and lack of professional development programs name a few (Mackeogh \& Fox, 2009; Panda \& Mishra, 2007; Reed, 2012, 2014; Seaton \& Schwier, 2014; Shannon, Francis, \& Torpey, 2012). Several studies show that a large number of faculty members are unwilling to adopt new technologies and have different anxiety sources which hinder 
their participation in online education (Chen \& Tseng, 2012; Sumak, Hericko, \& Pusnik, 2011; Yoo, Han, \& Huang, 2012).

In spite of the importance of faculty members' engagement in the online education programs, its drivers and barriers, there is not enough evidence investigating this aspect of online education in the context of Iranian online universities. The attempt of Sedghpor and Mirzaee (2009) is one of a few contributions in which the attitudes of teaching staff in technology and science faculties of universities in Tehran have been studied. Results of this study indicated that staff who were educated about online learning, and were aware of the benefits of online education, completely comprehended the necessity of the application of new innovations in education, and expressed their tendency to participate in online education training courses to develop their technical and educational skills. Although the research provided valuable information regarding faculty members' attitudes; it did not consider the factors preventing educators' engagement in online teaching comprehensively.

The reviewed literature discloses that faculty barriers for involvement in online education in Iranian online universities has not been investigated. The existing contributions focused more on success factors in ICT integration in the pre-university levels, not in higher education (Zamani, 2010; Zamani, NasrIsfahani, \& Shahbaz, 2009). In most recent research in the higher education field, only a few researchers studied faculty members' attitudes toward e-learning courses (Sedghpour \& Mirzaee, 2009), and there is no evidence of research on the other aspects of staff engagement preventers. By reviewing the existing body of knowledge, it is interesting to note that researchers categorised barriers in acceptance of online teaching in three main dimensions including personal, attitudinal, and organisational (Pajo \& Wallace, 2007). Therefore, in order to investigate online education barriers from the faculty members' perspective, it is essential to consider all three dimensions. The current study considering this gap, has aimed to develop a theoretical framework based on the existing body of knowledge, emphasising the cultural and perceived values of participants which are important in developing countries such as Iran.

\section{Theoretical framework of this research}

The online education models mostly have been created in/for the western world and then borrowed for developing countries, which are culturally completely different. This is seen as one of the problems which results in unsuccessful transition and adoption of online education in developing countries (Nawaz, Awan, \& Ahmad, 2011). The barriers of integration of ICT into education in developing countries have been explored by many researchers (Afshari, Bakar, Su Luan, Samah, \& Fooi, 2009; HossainKhan, Hasan, \& Clement, 2012; Ihmeideh, 2009). Reviewing these approaches, it can be seen that barriers in ICT integration into education generally can be classified into four broad categories, namely financial, political, institutional, social and cultural barriers. The obstacles involved with faculty members' technology implementation usually fall under the cultural factors (HossainKhan et al., 2012).

According to the literature, there is a long list of inhibiting factors for faculty members' participation in online teaching. Therefore, in order to develop a research instrument and incorporate the different factors mentioned in the literature, researchers followed the Pajo and Wallace (2007) classification of barriers, with modifications and cultural considerations. Hence, the barriers have been grouped into three main categories, namely: personal barriers (internal factors related to personal characteristics and behavioural habits of instructors), attitudinal inhibitors (internal factors related to attitudes and viewpoints of faculty members regarding features of the online learning environment), and contextual inhibitors (external factors associated with a lack of technical and organisational supports by the institution offering online courses).

\section{Personal barriers}

These obstacles refer to the factors and anxieties which are created because of conflicts between educators' habits and organisational change, resulting in loss of instructors' motivation and resistance to environmental changes. The main obstacle in this category which prevents academics participating in online education is resistance to change (Blin \& Munro, 2008; Ghashghagh, MahdiNezhad, \& Yaghoobi, 2011; Michael, 2013; Nawaz et al., 2011; Panda \& Mishra, 2007). This resistance arises from a lack of technological knowledge and skills, and the time constraints on faculty members for skills development 
and addressing this concern (Afshari et al., 2009; Bingimlas, 2009; HossainKhan et al., 2012; Reed, 2014). Scholars believe that some obstacles in this category such as computer skills and knowledge are more dominant in developing countries than in the western world (Bhuasiri, Xaymoungkhoun, Zo, Rho, \& Ciganek, 2012). The motivation to use technology is perceived as the most important factor which drives professional development for online course participation (Chen \& Tseng, 2012).

\section{Attitudinal barriers}

The principles of learning behaviour in online environments are different from traditional environments and this is what academic staff are faced with when they overcome their personal obstacles. In this situation, their attitudes about how to interact with new environments become a new challenge for them. The attitudinal barriers are mainly related to educators' anxiety regarding the quality of education (Mackeogh \& Fox, 2009; Rolfe, Alcocer, Bentley, Milne, \& Meyer-Sahling, 2006). The literature indicates that the perceived system quality significantly results in more satisfaction in online educators and this satisfaction leads to more intention to continue engagement with online learning systems (Islam, 2012; Mohammadi, 2015). Further to anxieties about quality, educators are concerned about emerging potential changes in their occupation such as loss of control, and greater workload (Mackeogh \& Fox, 2009; Rolfe et al., 2006; Seaton \& Schwier, 2014; Shannon et al., 2012). Furthermore, there are uncertainties about the consequences of publishing their intellectual property through the web, and about authority and job security for educators in online education (Bacow, Bowen, Guthrie, Lack, \& Long, 2012; Pajo \& Wallace, 2007). All these obstacles potentially promote negative attitudes in academic staff which discourage them from participating in online teaching.

\section{Contextual barriers}

This group of obstacles is related to the lack of technical and institutional supports for educators. These factors are fully dependent on the cultural environment, organisational relationships, missions and goals of each higher education institution. One of the main contextual barriers that prevents faculty members from participating in online teaching is the lack of recognition of educators' educational activities in this environment (Newton, 2003; Pajo \& Wallace, 2007). The time spent on online teaching (or production of online courses) is treated as less valuable than time spent on traditional teaching (or research) by university leaders. Therefore, the lack of credit towards tenure and promotion given for online course development and teaching is another large barrier to online faculty participation (Maguire, 2005). Another obstacle is insufficient rewards or payments to educators who produce or teach online courses. Unclear policies regarding copyright, and lack of technical support and training opportunities for instructors are other oft-cited institutional barriers (Bingimlas, 2009; Goktas, Yildirim, \& Yildirim, 2009; Mackeogh \& Fox, 2009; Michael, 2013; Reed, 2014).

By employing the above mentioned categorisation, researchers can determine which factors are more important for faculty members' participation in online teaching, and what should be done to improve their cooperation based on the cultural and organisational environment of the institution. Therefore, there are two key questions that need to be answered in this study:

1. What are the major factors that prevent the academic staff from participating in online teaching, and to what extent do each of these factors prevent academic staff from participating in these courses? and

2. Based on demographic variables, is there any difference between different groups of educators regarding the level of inhibition effect of these factors?

\section{Methodology}

In order to address the research questions, we conducted a survey in the University of Isfahan, which recently migrated to online education mode and is dealing with the challenge of lack of staff participation in online teaching. Population of the study included all the faculty members who were candidates for delivering online courses at this university. The courses are offered by three departments: Librarianship, Management and MBA. A total of 50 faculty members received questionnaires and $33(66 \%)$ were completed and returned. 
The research instrument was a questionnaire developed by the researchers. It was constructed based on the literature review, and comprised two main sections: (1) demographic characteristics of staff (e.g. gender, teaching experience, academic degrees, and their capabilities in International Computer Driving License [ICDL] skills), and (2) the list of factors extracted from the literature and recognised as preventing educators' participation in online teaching and categorised into three main categories, namely: personal barriers (six indices), attitudinal factors (five indices) and contextual factors (seven indices). The respondents were expected to express the degree to which they perceived each obstacle as operating within the University of Isfahan online teaching environment, using a 5-point Likert scale (very low $=1$ and very high $=5$ ). There was one open ended question asking about any barriers experienced by the participants during their teaching of online courses. The validity of the questionnaire was verified by members of the Isfahan University Council of Online Education. The reliability of this tool was verified by calculating Cronbach's alpha coefficient. Cronbach's alpha coefficient for barriers were $\alpha=0.73$ for the six indices of personal factors, $\alpha=0.66$ for the five indices of attitudinal factors, $\alpha=0.85$ for the seven indices of contextual factors, and $\alpha=0.88$ for all indices as a whole.

Table1

The demographic characteristics of respondents

\begin{tabular}{|c|c|c|c|c|c|}
\hline Gender & $N$ & Percent & Age (years) & $N$ & Percent \\
\hline $\begin{array}{l}\text { Male } \\
\text { Female }\end{array}$ & $\begin{array}{l}24 \\
9\end{array}$ & $\begin{array}{l}72.7 \\
27.3\end{array}$ & $\begin{array}{l}25-35 \\
36-45 \\
46-55 \\
\text { More than } 55\end{array}$ & $\begin{array}{l}19 \\
8 \\
3 \\
3\end{array}$ & $\begin{array}{l}57.6 \\
24.2 \\
9.1 \\
9.1\end{array}$ \\
\hline $\begin{array}{l}\text { Academic degree } \\
\text { Master } \\
\mathrm{PhD}\end{array}$ & $\begin{array}{l}9 \\
24\end{array}$ & $\begin{array}{l}27.3 \\
72.7\end{array}$ & $\begin{array}{l}\text { Academic position } \\
\text { Instructor } \\
\text { Assistant Professor } \\
\text { Associate Professor/higher }\end{array}$ & $\begin{array}{l}16 \\
14 \\
3\end{array}$ & $\begin{array}{l}48.5 \\
42.4 \\
9.1\end{array}$ \\
\hline $\begin{array}{l}\text { Teaching experience (years) } \\
1-10 \\
10-20 \\
20-30\end{array}$ & $\begin{array}{l}20 \\
10 \\
3\end{array}$ & $\begin{array}{l}60.6 \\
30.3 \\
9.1\end{array}$ & $\begin{array}{l}\text { Taken ICDL courses } \\
\text { Yes } \\
\text { No }\end{array}$ & $\begin{array}{l}8 \\
25\end{array}$ & $\begin{array}{l}24.2 \\
75.8\end{array}$ \\
\hline $\begin{array}{l}\text { Teaching with computer } \\
\text { (number of courses) } \\
\text { Zero } \\
1 \text { or } 2 \\
3 \text { or more }\end{array}$ & $\begin{array}{l}18 \\
8 \\
7\end{array}$ & $\begin{array}{l}54.5 \\
24.2 \\
21.2\end{array}$ & $\begin{array}{l}\text { Online teaching } \\
\text { (number of courses) } \\
\text { Zero } \\
1 \text { or } 2\end{array}$ & $\begin{array}{l}30 \\
3\end{array}$ & $\begin{array}{l}90.9 \\
9.1\end{array}$ \\
\hline Total & 33 & 100 & Total & 33 & 100 \\
\hline
\end{tabular}

After data collection, the quantitative data was analysed descriptively and inferentially, and the qualitative data attained from the open ended question in the questionnaire was analysed by coding and categorising. In descriptive statistics, demographic variables statistics were calculated and outlined in Table 1. Consequently, in order to answer the first research question by ranking educators' barriers for participation in online teaching, the Friedman test was employed.

Regarding the second research question to find out differences among faculty members in respect of the level of perceived impact of different obstacles, the $t$-Test or ANOVA were performed. In this stage, each of the demographic variables was considered as an independent variable and other variables were controlled. Considering the number of each group (instructors, assistant professors, associate professors or higher), one of these tests was employed. In order to examine the normality of distribution in each group, the Kolmogorov-Smirnov test was used. Application of the Levene's test on the data enabled the researchers to examine the homogeneity (equality) of the population variances in different groups. The Fisher's LSD test was implemented to conduct couple comparison among different groups of faculty members. The detailed results from all of these analyses are represented in the next section.

\section{Results and discussion}




\section{Major barriers for faculty members' participation in online courses}

In order to answer the first question, the researchers ranked the questionnaire items using the Friedman test. The ranking was performed in two stages: first, each category was ranked relative to other categories (personal, attitudinal and contextual), and then, each index in its category was graded. Comparing the ranks of categories to each other indicated that contextual barriers with rank of $(r=2.97)$ have the highest effect; attitudinal factors $(r=1.55)$, and personal factors $(r=1.48)$ are respectively in subsequent positions.

Table 2

Ranking the inhibitor indices of Isfahan faculty members' participation in online education

\begin{tabular}{|c|c|c|}
\hline Personal obstacles to faculty members' participation in online education & Mean & $r$ value \\
\hline $\begin{array}{l}\text { 1. unawareness and insufficient knowledge about online learning environment } \\
\text { and online teaching }\end{array}$ & 3.42 & 4.48 \\
\hline 2. insufficient knowledge regarding planning and producing online courses & 3.12 & 4.06 \\
\hline 3. anxiety about additional workload and decrease of free time & 2.96 & 3.98 \\
\hline $\begin{array}{l}\text { 4. anxiety about decreased time for other educational activities (academic and } \\
\text { research) }\end{array}$ & 2.96 & 3.64 \\
\hline 5. reluctance to learn necessary skills for online teaching & 2.06 & 2.48 \\
\hline 6. reluctance to get involved with new educational technologies & 2.06 & 2.35 \\
\hline
\end{tabular}

Attitudinal obstacles to faculty members' participation in online education

7. anxiety about the decrease in quality of education $3.76 \quad 4.38$

8. anxiety about decreasing interaction between students and instructors in online $\quad \begin{aligned} & 3.60 \\ & 4.02\end{aligned}$ environment

9. uncertainty about the quality of purchased courses and software provided by $\quad \begin{array}{lll}3.33 & 3.79\end{array}$ university

10. anxiety about illegal publishing of instructors intellectual property on the web $\quad \begin{array}{lll}2.90 & 3.14\end{array}$

11. anxiety about job security and decreasing control over teaching $\quad 3.60 \quad 2.38$

\begin{tabular}{|c|c|c|}
\hline \multicolumn{3}{|l|}{ Contextual obstacles to faculty members' participation in online education } \\
\hline $\begin{array}{l}\text { 12. anxiety about lack of essential hardware and software equipment for online } \\
\text { courses }\end{array}$ & 3.63 & 4.8 \\
\hline $\begin{array}{l}\text { 13. insufficient encouragement from university administrators regarding } \\
\text { instructors' orientation and persuasions }\end{array}$ & 3.39 & 4.41 \\
\hline 14. anxiety about lack of copyright rules for the author of electronic lessons & 3.30 & 4.23 \\
\hline 15. unawareness of technical support during the course & 3.09 & 3.88 \\
\hline 16. anxiety about lack of in-service continuous instructions about new jobs & 3.15 & 3.77 \\
\hline 17. anxiety about the lack of peer-collaboration in online courses & 3.00 & 3.62 \\
\hline 18. anxiety about absence of compensation policies (e.g. performance bonuses) & 2.90 & 3.29 \\
\hline
\end{tabular}

A comparison between the ranks of each index with other indices (Table 2) shows that among the contextual barriers, "anxiety about lack of essential software and hardware equipment for online courses" (index 12) was the most important source of faculty members' anxiety about teaching in online environments $(\mathrm{r}=4.8)$. Then, index 13 "insufficient encouragement of university administrators regarding instructors' orientation and persuasions" $(r=4.41)$ has been perceived as the next significant contextual 
barrier. This is in contrast with Panda and Mishra's (2007) findings in which credit towards promotion is perceived to be at the bottom of the motivator list for online teaching.

As Table 2 shows, across the personal barriers, index 1 "unawareness and insufficient knowledge about online learning environment and online teaching" and index 2 "insufficient knowledge about planning and producing online courses" ( $r=4.48$ and $r=4.06)$ were respectively the two most important personal inhibitors to faculty members participation in online teaching.

Among the attitudinal inhibitors, index 7 "anxiety about decreasing the quality of education" in online courses compared to the traditional ones and index 8 "anxiety about decreasing interactions between students and instructors in online environments" ( $r=4.38$ and $r=4.02)$ respectively were two most important barriers in the attitudinal domain. The findings of this research is in line with the results of research done by Zamani (2010) in which the highlighted barriers for ICT integration in Iranian schools are related to external and institutional factors such as technology cost, lack of administrators' supports, and lack of technical support (Zamani, 2010).

\section{Differences among faculty members' perceived impact of barriers based on their demographic information}

In this stage, each of the demographic variables was considered as an independent variable and other variables were controlled. Then, according to the number of the groups, $t$-Test or ANOVA were employed to analyze the data. Kolmogorov-Smirnov test also was performed to examine the normality of distribution in each group. The homogeneity (equality) of the population variances in different groups was examined using Levene's test. In all cases, there was no significant difference between the variance of the different groups (i.e. instructors, assistant professors, associate professors or higher). Furthermore in order to conduct couple comparison between groups, Fisher's LSD test was used. The results obtained are summarised as follows:

The demographic variables and personal barriers

Table 3

Comparing the inhibition effect of personal barriers according to the faculty members' academic position

\begin{tabular}{lllllll}
\hline Academic position & Mean & $\begin{array}{l}\text { Standard } \\
\text { deviation }\end{array}$ & $F$ & $\begin{array}{l}\text { Significance } \\
\text { level }\end{array}$ & $\begin{array}{l}\text { Significance } \\
\text { rate }\end{array}$ & $\begin{array}{l}\text { Test } \\
\text { power }\end{array}$ \\
\hline $\begin{array}{l}\text { Instructor (MA or PhD } \\
\text { candidate) }\end{array}$ & 18.25 & 4.64 & & & & .76 \\
Assistant Professor & 15.07 & 2.67 & 8 & .015 & .246 & .76 \\
Associate Professor/higher & 12.00 & 1.73 & & & & \\
\hline
\end{tabular}

Regarding the academic position and the level of perceived impact of personal obstacles (see Table 3), results indicate that the difference between constituted groups is significant: $p$ value $<.05 ; F(3,29)=$ $4.88, p=.015, \eta 2=.246$. The greater the academic position of faculty members, the less the perceived impact of personal barriers.

Table 4

The couple comparison (Fisher's LSD test) of the faculty members' personal barriers based on their academic position

\begin{tabular}{llll}
\hline Academic position & Mean difference & $\begin{array}{l}\text { Standard } \\
\text { error }\end{array}$ & $\begin{array}{l}\text { Significance } \\
\text { level }\end{array}$ \\
\hline Instructor Assistant Professor & 3.17 & 1.37 & $.028^{*}$ \\
Instructor Associate Professor/higher & 6.25 & 2.35 & $.013^{*}$ \\
\hline
\end{tabular}

* The difference between constituted groups is significant at $p<0.05$

Based on the couple comparison between groups performed by LSD test (Table 4), there is a significant difference between instructors (holding a masters degree or a $\mathrm{PhD}$ candidates) with other faculty members and the mean of personal barriers in this group is more than two other groups (i.e., Assistant Professors and Associate Professors/higher). 
Table 5

The ANOVA of the personal barriers among faculty members based on their experience in teaching with computer

\begin{tabular}{lllllll}
\hline $\begin{array}{l}\text { Teaching with computer } \\
\text { (number of courses) }\end{array}$ & Mean & $\begin{array}{l}\text { Standard } \\
\text { deviation }\end{array}$ & $F$ & $\begin{array}{l}\text { Significance } \\
\text { level }\end{array}$ & $\begin{array}{l}\text { Significance } \\
\text { rate }\end{array}$ & $\begin{array}{l}\text { Test } \\
\text { power }\end{array}$ \\
\hline Zero & 18 & .90 & & & & .206 \\
1 or 2 & 14.87 & 1.36 & 3.88 & .032 & .66 \\
3 or more & 13.71 & 1.45 & & & & \\
\hline
\end{tabular}

Considering faculty members' experience in teaching with computer as an independent variable indicates that the difference between constituted groups is significant at the level of $p$ value $<.05$ (see Table 5): $F$ $(2.30)=3.88, p=.032, \eta 2=.206$.

Table 6

The couple comparison of personal barriers among faculty members based on their online teaching experiences

\begin{tabular}{llll}
\hline $\begin{array}{l}\text { Online teaching } \\
\text { (number of courses) }\end{array}$ & Difference of mean & Standard error & $\begin{array}{l}\text { Significance } \\
\text { level }\end{array}$ \\
\hline Zero -1 or 2 & 3.12 & 1.63 & .066 \\
Zero -3 or more & 4.28 & 1.71 & $.018^{*}$ \\
\hline
\end{tabular}

* The difference between constituted groups is significant at $p<0.05$

Based on the couple comparison between groups done by LSD test (Table 6), there are significant differences between academics who did not have any experience in teaching online courses with especially those who had taught 3 or more units. As Table 6 shows, in all cases $p$ value $>.05$. Therefore, there is no significant difference regarding the level of personal barriers between constituted groups based on other independent variables including gender, age, academic degree, teaching experience, and ICDL courses participation.

The role of inhibition effects of attitudinal barriers

Table 7

Comparing the inhibition effect of attitudinal barriers among faculty members with MA and PhD degrees

\begin{tabular}{|c|c|c|c|c|c|c|}
\hline & MA & & $\mathrm{PhD}$ & & $t$ & $p$ \\
\hline Inhibition effect of & Mean & $\begin{array}{l}\text { Standard } \\
\text { deviation }\end{array}$ & Mean & $\begin{array}{l}\text { Standard } \\
\text { deviation }\end{array}$ & & \\
\hline attitudinal obstacles & 18.77 & 4.52 & 15.04 & 2.54 & 3.01 & .005 \\
\hline
\end{tabular}

Considering academic degree as an independent variable, the difference between constituted groups is significant at the level of $\mathrm{p}$-value $<.05$. The rate of inhibition of this category of obstacles for the educators' group who hold MA degrees is more than other group: $t(31)=3.01, p=.05$ (see Table 7). In all other cases, $p$ value $>.05$, and there is no significant difference related to inhibition effect of attitudinal inhibitors in classified groups based on independent variables including gender, age, academic degree, previous teaching experience in online courses, and ICDL courses participation.

The rate of inhibition effects of contextual factors

Table 8

The comparison of the inhibitor effect of contextual obstacles among male and female faculty members

\begin{tabular}{lllllll}
\hline & Female & & Male & & $t$ & $p$ \\
\hline & Mean & $\begin{array}{l}\text { Standard } \\
\text { deviation }\end{array}$ & Mean & $\begin{array}{l}\text { Standard } \\
\text { deviation }\end{array}$ & & \\
$\begin{array}{l}\text { Inhibition rate of } \\
\text { contextual obstacles }\end{array}$ & 30.44 & 7.23 & 24.08 & 5.39 & -2.74 & .01 \\
\hline
\end{tabular}

Considering gender as an independent variable, the difference between constituted groups is significant at the level of $p$ value $<.05$. The rate of inhibition of this category of obstacles for the female educators is more than for the male group: $t(31)=-2.74, p=.01$ (see Table 8). In all other cases, $p$ value $>.05$, 
therefore, there is no significant difference related to inhibition effect of contextual inhibitors among the constituted groups based on other independent variable including age, academic degree, teaching experience, ICDL courses participation, and teaching with computer.

\section{Discussion}

The findings of this study reveal that the external contextual inhibitors (lack of essential supports from the university) were the main barriers that discourage faculty members from participating in online teaching. Among these factors, anxiety about lack of necessary equipment (software, hardware and internet bandwidth) and insufficient actions of university administrators regarding educators' orientation have been perceived as the most prominent obstacles for academic staff in becoming involved with online courses. Anxiety about unwillingness of colleagues to cooperate and anxiety about absence of compensation policies (e.g., performance bonuses) were the least important inhibitor factors. Although faculty members of University of Isfahan are interested to undertake online teaching, the results indicated they are concerned about the quality of their teaching in new environment and are waiting for practical supportive actions of university administers to provide necessary equipment and to hold explanatory sessions and training courses.

The results confirm the findings of previous studies that focused on the significant role of external inhibitors which were related to context and environment of learning (Zamani et al., 2009). According to the current research, external barriers which are listed as contextual inhibitors (e.g., lack of essential equipment for online courses with rank 4.8) are more influential inhibitors than internal inhibitors (e.g., reluctance to learn new skills with $r$ value $=2.48$, and reluctance to involve with new technologies with $r$ value $=2.35$ ). Similarly in other developing countries, the technology-related barriers such as technical infrastructure and technology support challenges have been reported as the dominant barriers (e.g., HossainKhan et al., 2012). Although the findings do not support the notion of Bhuasiri et al. (2012) who emphasised the dominance of personal barriers (e.g., lack of knowledge and ICT skill) in the developing countries, still some inhibitors in this category are highly ranked (e.g. insufficient knowledge about online learning environment and online teaching with $r$ value $=4.48$, and insufficient knowledge regarding planning and producing online courses with $r$ value $=4.06$ ). These barriers refer to the educators' concerns about online pedagogy.

According to the results shown in Table 8, the inhibitor rate of contextual obstacles for women is more than that for men. Based on the researchers' opinion and considering the cultural context of Iran, this may be because women feel they need more organisational support to become involved in innovative actions and the challenge of new technologies than men. The results also indicate that insufficient knowledge of faculty members regarding the required skills in online education and their anxiety about decreased interaction with their students-which consequently leads to a decrease in quality of education and lack of transfer of suitable learning experiences to students-are the most important internal inhibitors related to personal behavioural patterns and attitudes of faculty members (personal and attitudinal inhibitors).

These results are compatible with the findings of Sedghpor and Mirzaee (2009), in which the absence of Iranian instructors' knowledge regarding the requirements of online education and their unawareness of special teaching strategies related to this environment, are factors that prevent faculty members from participating in online courses. It may be inferred that the possible reason for this is because most of the faculty members in Iran have graduated from traditional universities and have therefore been prepared to teach in on-campus classrooms where the teacher is the sage on the stage and all teaching principles and techniques are oriented to face to face interaction and communications. As a result, faculty members perceive face to face interaction as one of the major necessities in teaching and learning, whereas teaching and learning in online environments is based on mental construction of knowledge by learners and exchange of educational ideas between students and educators by writing messages. Consequently, decreased levels of face to face interaction can be one of the considerable obstacles for faculty members' participation in online teaching. In contrast, factors such as anxiety about the job security and unwillingness to challenge new educational technologies are less significant.

Using the results shown in Tables 3 to 7 to answer the second research question, it is indicated that internal inhibitors (personal and attitudinal) have more inhibition effect for groups with a lower level of academic rank and academic degree. This is not surprising, as in the Iranian higher education system, in 
almost all undergraduate programs and to some extent masters programs, the main focus is on knowledge transmission, while at the $\mathrm{PhD}$ level, the focus is on research activities. In this context, the second group are usually more engaged with ICT tools and techniques. Thus, faculty members who are at lower levels of academic rank (instructor or MA teachers) and hold lower academic degrees, have had less opportunities to experience activities that may prepare them mentally and behaviourally for online education. Consequently, being in this position causes negative attitudes and resistance against adoption of new educational technologies for these groups of educators. In this regard another effective factor which needs to be taken into account is teaching courses with computer technologies. The faculty members who had more experience in teaching with computer technologies have acquired suitable experiences and necessary skills to challenge new technologies. Therefore they are more prepared than their colleagues to participate in online education and personal inhibitors are less effective in preventing their participation in online teaching.

The results from the open ended question indicated that most important inhibitors are pedagogical and traditional teaching habits which are related to the differences in the nature of online and traditional teaching environments. Respondents liked the face to face relationships with their students in the on campus classes. One of them hated that in online environments everything is artificial. Some of them expressed the belief that motivating students for participating in the online courses is the major challenge for online teachers. They believed that motivating students in online courses for deep learning is more difficult than in on-campus classes, due to the low rate of employment of online university graduates in recent years, resulting from a lack of acceptance of the online degrees by employers. This notion is also highlighted by a number of scholars through the literature (e.g., Columbaro \& Monaghan, 2009; Sarlak \& Abolhasani, 2008). Some cultural barriers such as instructors' intention to work individually, and lack of team work skills are mentioned to be influential for faculty members' involvement in online courses. Accommodation of the differences between on-campus and online teaching is another result that should be considered. Pedagogical changes and a learner centered approach should be discussed in faculty members' training courses.

\section{Implications}

This research presents a number of significant implications for promoting effective participation of educators in online education programs and the continuance of this participation in developing countries, specifically in Iran. Before mentioning the implications it should be noted that Iran has a centralised educational system. It is different from decentralised systems in which universities are allowed to establish a new course or have a new mode for delivering education such as offering online courses by educational institutions. This means that in the different levels of the Iranian educational systems, that is K-12 and higher education institutions, all educational decisions including allocating budgeting, purchasing tools and equipment, training human forces, determining the teaching methods by instructors are taken by top administers of Ministry of Education and Ministry of Higher education, and dictated to other educational subsystems. Another big issue in countries such as Iran is that the educational policy changes with changes to the country's political situation and even with changes to the top administers. In this situation, codification of one coherent policy is essential, because, it will not change with changing the political situations or the replacement of top administrators. In addition to codification of one coherent policy for designing new courses by the Ministry of Higher Education, it is essential to determine special policies for removing all contextual inhibitors as the main obstacles for educators to participate in online education. In this regard, attention to following actions might be beneficial:

- Defining missions and goals of the organisation regarding integration of online education, clearly. This definition should be declared in a framework of compiled and explicit public statements. The timing process to transfer the organisation to new situation should be specified too, and the required time for educators' preparation must be included in this process.

- Redefining the organisational supports and recognition policies for faculty members' participation in online teaching and best practices.

- Offering training courses which are compatible with the needs and time constraints of educators and providing necessary equipments and facilities. 
In order to increase the level of information and knowledge of educators regarding online education and the benefits of participation in these courses, organising e-Learning conferences would help to create awareness and interest for educators regarding this educational approach. By increasing the level of knowledge in this field, the internal motivation of educators to face new educational technologies would be increased gradually, and they would be mentally prepared to participate and to select this method for their teaching. After this stage, holding suitable training courses may be useful for them to get practically prepared for technology based teaching.

To convince academics to participate in online teaching and to create a positive viewpoint of success for them, explanatory sessions may enable them to improve their attitudes in such a way that they understand that application of online technologies will not push them to the margins and will not decrease their control over education. On the contrary, they should be convinced that new technologies could increase their efficiency. To reach this goal we may use practical examples based on colleagues' experiences and the personal creativity of educators themselves.

Along with holding explanatory sessions for educators there must be a range of training programs for them. Voluntary participation in the abovementioned courses would decrease complaints and negative beliefs and attitudes. Teaching and learning processes which are compatible with needs of educators and in-service time may be a better choice to increase the occupational skills of academic staff.

\section{Conclusion}

This research aimed to address some concerns regarding why academic staff are not inclined to participate in online teaching in Iranian higher education institutions. In order to achieve this, the faculty members in one of the top universities that has migrated to online education mode were surveyed. The results of this study are consistent with results from other research in developing countries in which contextual factors have been perceived as the most important drivers in adoption or rejection of innovative technologies. The inhibitor rate of contextual obstacles for women is more than that for men. The educators' concerns about lack of essential equipment (software, hardware and internet bandwidth) and insufficient knowledge about online pedagogy and support from institution administrators were viewed as the main barriers for faculty members' participation in online teaching. Therefore to adopt the new educational environment, there should be various supports from the institution especially in the developing countries context. Faculty members need to receive professional development training regarding online pedagogy and its requirements to be encouraged for online teaching participation to have a more successful transition in their teaching mode.

\section{References}

Afshari, M., Bakar, K. A., Su Luan, W., Samah, B. A., \& Fooi, F. S. (2009). Factors affecting teachers' use of information and communication technology. International Journal of Instruction, 2(1), 77-104. Retrieved from http://sh.st/st/787f28ed3e745c14417e4aec27303038/www.eiji.net/dosyalar/iji_2009_1_5.pdf

Al-alak, B. A., \& Alnawas, I. A. M. (2011). Measuring the acceptance and adoption of e-learning by academic staff. Knowledge Management \& E-Learning: An International Journal, 3(2), 201-221. Retrieved from http://kmel-journal.org/ojs/index.php/online-publication/article/view/33/84

Bacow, L. S., Bowen, W. G., Guthrie, K. M., Lack, K. A., \& Long, M. P. (2012). Barriers to adoption of online learning systems in US higher education. New York: ITHAKA. Retrieved from http://el.teacherworld.com/elearningbarriers.pdf

Benson, V., Anderson, D., \& Ooms, A. (2011). Educators ' perceptions, attitudes and practices: Blended learning in business and management education. Research in Learning Technology, 19(2), 143-154. doi:10.1080/21567069.2011.586676

Bhuasiri, W., Xaymoungkhoun, O., Zo, H., Rho, J. J., \& Ciganek, A. P. (2012). Critical success factors for e-learning in developing countries: A comparative analysis between ICT experts and faculty. Computers \& Education, 58(2), 843-855. doi:10.1016/j.compedu.2011.10.010

Bingimlas, K. A. (2009). Barriers to the successful integration of ICT in teaching and learning environments: A review of the literature. Eurasia Journal of Mathematics, Science \& Technology Education, 5(3), 235-245. Retrieved from http://ejmste.com/v5n3/EURASIA_v5n3.pdf 
Blin, F., \& Munro, M. (2008). Why hasn't technology disrupted academics' teaching practices? Understanding resistance to change through the lens of activity theory. Computers \& Education, 50(2), 475-490. doi:10.1016/j.compedu.2007.09.017

Bolliger, D. U., Inan, F. A., \& Wasilik, O. (2014). Development and validation of the online instructor satisfaction measure (OISM). Educational Technology \& Society, 17(2), 183-195. Retrieved from http://ifets.info/journals/17_2/15.pdf

Chen, H. R., \& Tseng, H. F. (2012). Factors that influence acceptance of web-based e- learning system for the in-service education of junior high school teachers in Taiwan. Evaluation and Program Planning, 35(3), 398-406. doi:10.1016/j.evalprogplan.2011.11.007

Columbaro, N. L., \& Monaghan, C. H. (2009). Employer perceptions of online degrees: A literature review. Online Journal of Distance Learning Administration, 12(1), 1-10. Retrieved from http://eric.ed.gov/?id=EJ869269

Ghashghagh, M. M., MahdiNezhad, V., \& Yaghoobi, N. M. (2011). Assessing factors affecting the tendancy to use electronic learning systems among faculty members. Magazine of Elearning Distribution In Academy (MEDIA), 2(3), 28-38. Retrieved from http://mediaj.ir/online/browse.php?a_code=A-10-6-37\&slc_lang=en\&sid=1

Goktas, Y., Yildirim, S., \& Yildirim, Z. (2009). Main barriers and possible enablers of ICTs integration into pre-service teacher education programs. Educational Technology \& Society, 12(1), 193-204. Retrieved from http://www.jstor.org/stable/jeductechsoci.12.1.193

HossainKhan, M. S., Hasan, M., \& Clement, C. K. (2012). Barriers to the introduction of ICT into education in developing countries: The example of Bangladesh. International Journal of Instruction, 5(2), 61-80. Retrieved from http://www.e-iji.net/dosyalar/iji_2012_2_4.pdf

Ihmeideh, F. M. (2009). Barriers to the use of technology in Jordanian pre-school settings. Technology, Pedagogy and Education, 18(3), 325-341. doi:10.1080/14759390903255619

Islam, A. N. (2012). The role of perceived system quality as educators' motivation to continue e-learning system use. Transactions on Human-Computer Interaction, 4(1), 25-43. Retrieved from http://aisel.aisnet.org/thci/vol4/iss $1 / 2$

Kowalczyk, N. K. (2014). Perceived barriers to online education by radiologic science educators. Radiologic Technology, 85(5), 486 - 493. Retrieved from http://europepmc.org/abstract/med/24806051

Mackeogh, K., \& Fox, S. (2009). Strategies for embedding e-learning in traditional universities: Drivers and barriers. Electronic Journal of E-Learning, 7(2), 147-154. Retrieved from http://doras.dcu.ie/2166/1/ecel_2008.pdf

Maguire, L. L. (2005). Literature review - Faculty participation in online distance education: Barriers and motivators. Online Journal of Distance Learning Administration, 8(1), 1-15. Retrieved from http://nurs.westga.edu/ distance/ojdla/spring81/maguire81.pdf

McNeil, D. R. (1990). Wiring the ivory tower: A round table on technology in higher education. Washington, DC: Academy for Educational Development.

Michael, K. (2013). Virtual classroom: Reflections of online learning. Campus-Wide Information Systems, 29(3), 156-165. doi:10.1108/10650741211243175

Mohammadi, H. (2015). Investigating users ' perspectives on e-learning: An integration of TAM and IS success model. Computers in Human Behavior, 45(1), 359-374. doi:10.1016/j.chb.2014.07.044

Nawaz, A., Awan, Z., \& Ahmad, B. (2011). Integrating educational technologies in higher ducation of the developing countries. Journal of Education and Practice, 2(2), 1-13. Retrieved from http://iiste.org/Journals/index.php/JEP/article/view/176

Newton, R. (2003). Staff attitudes to the development and delivery of e-learning. New Library World, 104(10), 412-425. doi:10.1108/03074800310504357

Pajo, K., \& Wallace, C. (2007). Barriers to the uptake of web-based technology by university teachers. International Journal of E-Learning \& Distance Education, 16(1), 70-84. Retrieved from http://www.ijede.ca/index.php/jde/article/view/171/127

Panda, S., \& Mishra, S. (2007). E-learning in a Mega Open University: Faculty attitude, barriers and motivators. Educational Media International, 44(4), 323-338. doi:10.1080/09523980701680854

Reed, P. (2012). Awareness, attitudes and participation of teaching staff towards the open content movement in one university. Research in Learning Technology, 20(18520), 1-14. doi:10.3402/rlt.v20i0.18520

Reed, P. (2014). Staff experience and attitudes towards technology-enhanced learning initiatives in one faculty of health and life sciences. Research in Learning Technology, 22(22770), 1-23. Retrieved from http://dx.doi.org/10.3402/rlt.v22.22770 
Richardson, J. C., \& Alsup, J. (2015). From the classroom to the keyboard: How seven teachers created their online teacher identities. International Review of Research in Open and Distributed Learning, 16(1), 142-167. Retrieved from http://irrodl.insurancestack.com/index.php/irrodl/article/download/1814/3253

Rolfe, V., Alcocer, M., Bentley, E., Milne, D., \& Meyer-Sahling, J. (2006). Academic staff attitudes towards electronic learning in arts and sciences. Proceedings of The 5th European Conference on elearning (pp. 317-322). Winchester: Academic Conferences Limited. Retrieved from http://www.eurodl.org/?p=archives\&year=2008\&halfyear=1\&article=313

Sarlak, M. A., \& Abolhasani, A. (2008). Trust in virtual universities. Journal of Social Sciences, 4(3), 237-245. doi:10.3844/jssp.2008.237.245

Seaton, J. X., \& Schwier, R. (2014). An explanatory case study of online instructors: Factors associated with instructor engagement. International Journal of E-Learning \& Distance Education, 29(1), 1-16. Retrieved from http://www.ijede.ca/index.php/jde/article/view/870

Sedghpour, B. S., \& Mirzaee, S. (2009). Attitudinal challenges of the members of faculty in electronic education. Technology and Education Journal, 3(1), 77-87. [In Persian]

Shannon, S. J., Francis, R. L., \& Torpey, G. T. (2012). Barriers to adoption of blended learning and online feedback and assessment by sessional staff. Proceedings of The 46th Annual Conference of the Architectual Science Association (ANZAcA), Gold Coast, Australia: Griffith University, (pp. 14-16). Retrieved from http://anzasca.net/wp-content/uploads/2014/02/p83.pdf

Sumak, B., Hericko, M., \& Pusnik, M. (2011). Factors affecting the adoption of e-learning: A metaanalysis of existing knowledge. Proceedings of The Third International Conference on Mobile, Hybrid, and On-line Learning, Guadeloupe, France, (pp. 31-35). Retrieved from http://www.thinkmind.org/download.php?articleid=elml_2011_2_20_50068

Yoo, J. S., Han, S. H., \& Huang, W. (2012). The role of intrinsic motivators and extrinsic motivators in promoting e-learning in the workplace: A case from South Korea. Computers in Human Behavior, 28(3), 942-950. doi:10.1016/j.chb.2011.12.015

Zamani, B. E. (2010). Successful implementation factors for using computers in Iranian schools during one decade (1995-2005). Computers \& Education, 54(1), 59-68. doi:10.1016/j.compedu.2009.07.004

Zamani, B. E., NasrIsfahani, A. R., \& Shahbaz, S. (2009). Isfahan high schools teachers' utilization of ICT. British Journal of Educational Technology, 41(5), E92-E95. doi:10.1111/j.14678535.2009.01000.x

Corresponding author: Azam Esfijani, esfijani@gmail.com

Australasian Journal of Educational Technology (C) 2016.

Please cite as: Zamani, B.E., Esfijani, A., \& Abdellahi Damaneh, S.M. (2016). Major barriers for participating in online teaching in developing countries from Iranian faculty members' perspectives. Australasian Journal of Educational Technology, 32(3), 38-49. 